\title{
A study on the international students' perception and norms in Taiwan
}

Chou, Chuing Prudence

National Chengchi University, Taiwan, ROC (iaezcpc@nccu.edu.tw)

Roberts, Amy

University of Wyoming,USA (aroberts@uwyo.edu)

Ching, Gregory S.

Lunghwa University of Science and Technology, Taiwan, ROC (gregory_ching@yahoo.com)

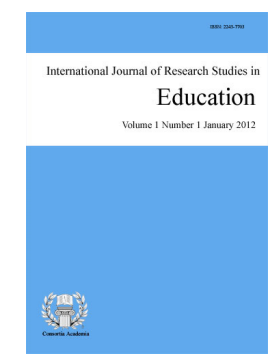

ISSN: 2243-7703 Online ISSN: 2243-7711

OPEN ACCESS

\section{Abstract}

Trends in Taiwan higher education reflect traditional East Asian patterns, which show a substantial numbers of university students from Taiwan studying in the United States and Britain. In a recent worldwide student mobility report, findings suggest that an increased flow of international students coming from the United States and European countries to the Asia Pacific Rim is at an all time high. However, if the number of inbound international students' is subtracted with the number of outgoing Asian students, results are still not that promising. Hence, in order to increase the influx of international students in Taiwan, a deeper understanding of their perceptions and norms should be undertaken. This article details a quantitative study conducted during the 2009-2010 academic year in Taiwan. In scope it details an empirical study exploring the dispositions of international students in terms of their academic and social spheres. The use of quantitative method provided clarity and extended critical interpretations of the issues and dilemmas surrounding the international student experience in Taiwan.

Keywords: international student; internationalization; globalization; Taiwan; social norms; cultural perceptions 


\section{A study on the international students' perception and norms in Taiwan}

\section{Introduction}

The Institute of International Education (IIE) definition of an international student is, one who undertakes all or part of his/her higher education experience in a country other than the home country (Project Atlas, 2004). More broadly, cross-border education is classified as a borderless asset of the global education industry that redefines traditional patterns and trends of international student mobility (Kwiek, 2005). Since 1995 the total number of international students has all but doubled, reaching nearly 2.7 million (OECD, 2006). Correspondingly the demand for global cross-border education is forecasted to increase from 1.8 million international students in 2000 to 7.2 million in 2025 (Bohm, Meares, \& Pearce, 2002). Analysts predict that 70 percent of the global demand will be generated within the Asia Pacific region (Olsen, 2003).

In the contemporary era many nations have shifted foreign student policies from an aid approach to a trade rationale (Smart \& Ang, 1993). Thus, signaling that cross-border education is a commodity of free trade rather than a public responsibility (Kirp, 2003). Given this the market for international students has become a dynamic growth industry sustained by universities, government agencies, private corporations, and entrepreneurs motivated by financial profit (Altbach, 2003). National governments are keen to sustain active involvement through their Ministries of Education or dedicated promotional agencies (Kemp, 1995), that capitalize on the benefits of international student populations as linked to skill migration, economic growth, public diplomacy, and research associated with a knowledge society (Kishun, 2007).

Trends in Taiwan reflect traditional East Asian patterns; substantial numbers of university students from Taiwan studied in the United States and Britain while very few incoming international students chose the island nation as a host destination. Foreign students are the bridges of a nation to the international society. The number of students studying in Taiwan indicates the level of internationalization and international competitiveness of the nation's education, as well as representing the nation's power and ability to attract foreigners. In 2007 , the total number of students (including degree-level, exchange, and language study students) reached 17,742, which registers an increase of 3,263, compared to the 14,479 count in 2006 (Ko, 2008). Between 2001 and 2005 incoming international student enrollments from Central and South America increased 208 percent and 95 percent from European nations. Incoming students from Vietnam comprise the largest group, followed by Malaysia, Indonesia, Japan and the United States. Scholars attribute the rising population of incoming international students to the global popularity of Mandarin studies, the growing reputation of Taiwan universities as world class institutions, and availability of scholarships administered by the Taiwan Ministry of Education (MOE) (Ko, 2008). Furthermore, in a recent worldwide student mobility report, findings suggest that an increased flow of international students coming from the United States and European countries to the Asia Pacific Rim is at an all time high (JWT Education, 2008). However, if the number of inbound international students' is subtracted with the number of outgoing Asian students, results are still not that promising. Hence, in order to increase the influx of international students in Taiwan, a deeper understanding of their perceptions and norms should be undertaken.

\section{Literature review}

The examination of globalization and internationalization as distinct processes is essential for serious scholarship addressing contemporary trends in higher education. Globalization is a multifaceted phenomenon enveloped by economic, social, political and cultural dimensions that meld 21 st century higher education to international endeavors. The impact of globalization poses challenges to the role of nations as the sole providers of higher education and to academic communities as the primary voice for education decision-making. Processes of globalization within university settings transcend the integration of research, the use of English as the 
language of academia, the expanding international market for scholars, the growth of multinational publishing, and reliance on information technology (Altbach, 2003; Chin \& Ching, 2009).

The examination of international student mobility trends and patterns is well established by a body of research identified with the push-pull framework (Agarwal \& Winkler, 1985; Altbach, 1997; Cummings, 1993; Fry, 1984; Sirowy \& Inkeles, 1985). This research suggests that international student's progress through developmental stages of decision making beginning with commitments to study internationally and ending with the selection of host institutions. Researchers defined research push factors as conditions in home nations that engender interest in university education beyond national borders. Pull factors are attributes of a host nation that attract international students and affect the decision-making process for study at particular institutions (Mazzarol, 1998).

Agarwal and Winkler (1985) quantified pull factors for the United States as a host destination among students from 15 developing nations. They noted that the percentage of international students enrolling in United States universities has declined in recent years. This shift was attributed to the rising cost of United States tertiary education and the multitude of university program options in students' home nations. As such a contemporary trend is involves nations that traditionally sent large numbers of students abroad; in recent years these nations have also become successful international centers via the offering of degree programs in English at a low expense (Chan \& Ng, 2008). In a related study McMahon (1992) used a push-pull model to statistically examine the mobility patterns of international students from 18 developing countries. Findings suggested that student flow was dependent on the level of economic wealth, the degree of involvement of the destination country in the world economy, and the priority placed on education by the home nation government. McMahon noted a negative correlation between economic prosperity in home countries and the volume of international student flow. Significant pull factors included the size of host nation economies and their political interests as evidenced by foreign assistance, transnational cultural links, and availability of international student scholarships.

In a summative study Massarol (1998) surmised that six pull factors consistently influence students' selection of host nations and institutions. The overall level of knowledge, access to information, and awareness of the destination nation within students' home country represented a critical pull factor. The reputation of host institutions for quality and the recognition of their degrees in students' home nations were significant attributes of this factor. A second pull factor was the number of personal recommendations students received from parents, relatives, friends and gatekeepers. The third factor related to financial issues, including the expense of fees, living, and travel along with social costs, such as crime, safety and racial discrimination. The presence of other students from home nations and the option for part-time work were important attributes of this factor. Additional factors included: the environment, as related to perceptions about the climate in the host country; the geographic and time proximity between home and host nations; and social links defined as family or friends residing in the destination country.

The utility of the push-pull framework is apparent given the identification of factors affecting mobility patterns and trends of university international students from developing nations. Yet in some respects this framework compromises attention to the complexities associated with the international student experience. Limitations are noted in terms of the exclusion of international students from developed countries who pursue tertiary level education in either developing or other developed nations. The design of the push-pull framework, moreover, locates the national identity of international students as a reference for commonality; thus international students are defined as a homogenized group rather than as clusters of individuals who have significant differences between and within their nationalities.

Critics argue that scholarship addressing the complexities of the international student experience remains on the fringe of cross-border education literature due in part to a deficit of concepts to articulate the multidimensional complexities of international students' experiences. In response, a transnational lens is offered 
to illuminate theoretical and critical interpretations intended to examine the "persistent pull of 'locality' as a social space of identity formation" (Smith \& Guarnizo, 1998, p. 22)

\section{Methodology}

Scholars, who conduct research involving international dimensions, note the importance of primary sources as a viable option for data collection (Pinar, Reynolds, Slattery, \& Taubman, 1996). In response the investigation was initiated with a review of sources to develop a contemporary reference for the dilemmas and issues of globalization in Taiwan. The inspection of written documents such as books, periodicals, newspapers, and legal documents to gain a foundation for the history, geography, ecological needs, and community efforts at work in Taiwan were ongoing during all stages of investigation.

The research was designed as a quantitative research method study. Beginning research questions included:

1. What are the benefits and dilemmas associated with the international student population in terms of institutional commitments for the expansion of internationalization for Taiwan's higher education institutions?

2. What are the interpretations of participants in regard to the issues and dilemmas surrounding the international student experience?

The survey respondents included 648 degree seeking international students from 23 countries. The survey was used to gather information at a particular point in time with the intention of describing the nature of existing conditions of international student in Taiwan universities (Cohen, Manion, \& Morrison, 2007). Given this focus the survey was organized by section: Section One: Experiences before and after coming to Taiwan dealt with the logistical and emotional aspects of student mobility, Section Two: Educational experiences in Taiwan, addressed reasons for choosing Taiwan and particular universities, Section Three: Social norms, examined international students' circle of friends, social interaction norms, and classroom norms, Section Four: Cultural norms, focused on the cultural aspect of the international students' experiences in Taiwan, and Section Five International Students' Demography, detailed background information including international students' social status and scholarship information.

The study utilizes an online survey to gather the information regarding the international students all over Taiwan. The design of the online surveys were kept to a minimum and layout is user friendly, instructions are clear and simple, thus helped in increasing the completion rate of the survey (Dillman, 1999; Dillman, Tortora, \& Bowker, 1998; Dillman, Tortora, Conradt, \& Bowker, 1998). The survey data was statistically analyzed using the mean, standard deviation, frequency and percentage, correlations, and other cross-tabulations to determine the various descriptive summaries of the survey. A revised survey questionnaire was used based on Roberts, Chou, and Ching's (2010), and Roberts and Ching's (2010) international student survey. The survey questionnaire was administered on a voluntary basis in October 2009. An email was sent to all the international student offices all throughout Taiwan. The questionnaire was written in two versions: English and Chinese which required approximately 10-20 minutes for completion.

A total of 648 participants' representative of 23 countries completed the questionnaire. Table 1; show that Mandarin Chinese was the predominant first language of participants (39\%), which would indicate that most of the international students are from countries such as Mainland China, Macau, and Hong Kong. This is then followed by Vietnam (10\%), and Indonesian (9\%). Participants' second languages included English (53\%), Mandarin Chinese (20\%), and Malaysian (7\%). Around $76 \%$ of the sample consisted of international students studying abroad for the first time. In addition, around $80 \%$ of the respondents are degree seeking students, with the remaining participants as exchange program students (7\%) and Mandarin Chinese Language students (2\%). Data gathered from the survey questionnaire were encoded and analyzed using the Statistics Package for Social Science (SPSS) version 15. Internal consistency using Lee Cronbach's (1951) coefficient alpha (Cronbach's 
A study on the international students' perception and norms in Taiwan

alpha) was computed at 0.89, suggesting a high level (Nunnally \& Bemstein, 1994). Descriptive analysis included the mean, standard deviation (SD) and cross-tabulation of participants' multiple responses for identified questions.

\section{Table 1}

Participant demographics $(N=648)$

\begin{tabular}{|c|c|c|c|c|}
\hline Items & $n$ & $\%$ & $M$ & $S D$ \\
\hline Age & 648 & & 24.63 & 6.39 \\
\hline \multicolumn{5}{|l|}{ Gender } \\
\hline Male & 297 & 46 & 23.87 & 5.16 \\
\hline Female & 346 & 54 & 25.28 & 7.23 \\
\hline \multicolumn{5}{|l|}{ First language } \\
\hline Mandarin Chinese & 251 & 39 & & \\
\hline Vietnamese & 67 & 10 & & \\
\hline Indonesian (Bahasa) & 61 & 9 & & \\
\hline Spanish & 47 & 7 & & \\
\hline English & 37 & 6 & & \\
\hline Japanese & 27 & 4 & & \\
\hline Malaysian (Malay) & 21 & 3 & & \\
\hline Cantonese & 19 & 3 & & \\
\hline Thailand (Thai) & 15 & 2 & & \\
\hline Korean & 13 & 2 & & \\
\hline \multicolumn{5}{|l|}{ Second language } \\
\hline English & 345 & 53 & & \\
\hline Mandarin & 131 & 20 & & \\
\hline Malaysian (Malay) & 44 & 7 & & \\
\hline \multicolumn{5}{|l|}{ Enrolled program type } \\
\hline Degree Seeking & 526 & 81 & & \\
\hline Exchange Program Student & 43 & 7 & & \\
\hline Chinese Mandarin Language Center & 12 & 2 & & \\
\hline \multicolumn{5}{|l|}{ Study abroad experience } \\
\hline Yes & 112 & 17 & & \\
\hline None & 493 & 76 & & \\
\hline \multicolumn{5}{|l|}{ Work experience in Taiwan } \\
\hline Yes & 179 & 28 & & \\
\hline None & 424 & 66 & & \\
\hline
\end{tabular}

\section{Results and Discussions}

\subsection{Experiences before and after coming to Taiwan}

Section one depicts the experiences before and after coming to Taiwan, which dealt with the logistical and emotional aspects of student mobility. Choosing a host nation involves decisions made with high involvement and commitment, due in part to the expanding options for study abroad destinations around the globe (Cubillo, Sanchez, \& Cervino, 2006). One of the most promising factors in Taiwan's higher education is the presence of scholarship opportunities for international students.

Table 2 shows that of the 432 of the 648 respondents (67\%) received scholarships offered by either the Taiwan Scholarship Program (jointly funded by the MOE, the Ministry of Foreign Affairs, the Nation Science 
Chou, C. P., Roberts, A., \& Ching, G. S.

Council, and the Ministry of Economic Affairs) or the MOE Mandarin Enrichment Scholarship Program (funded by the MOE). Applications for both scholarships are submitted to Taiwan overseas missions located in students' home nations. Majority are in scholarships given through their universities here in Taiwan, with a value of 118 or $27 \%$. This is then followed by the Ministry of Foreign Affairs scholarship, which is given to countries that have diplomatic ties with Taiwan, with a value of 111 or $26 \%$. The third largest is the scholarship given by the Ministry of Education (more commonly called the Taiwan Scholarship), with a value of 104 or $24 \%$. When asked regarding how the international students gathered the information regarding the scholarship offers. Respondents responded that majority of them learnt about the scholarship in their school back in their country, with a value of 274 or $64 \%$. This is followed by word of mouth transfers from their peers and friends back home, with a value of 136 or $31 \%$. The third is self-research with a value of 69 or $16 \%$.

\section{Table 2}

Scholarship type and expenditures $(N=432)$

\begin{tabular}{lrr}
\hline \multicolumn{1}{c}{ Items } & $n$ & $\%$ \\
\hline Scholarship type & & 14 \\
Ministry of Foreign Affairs (MOFA) & 61 & 24 \\
Ministry of Education (MOE) - Taiwan Scholarship & 104 & 0 \\
Huayu Enrichment Scholarship & 2 & 2 \\
National Science Council & 9 & 26 \\
Ministry of Economic Affairs & 111 & 27 \\
Others & 118 & \\
Information regarding the scholarship & & 14 \\
Taipei Economic and Trade Office (TECO) & 61 & 63 \\
School & 274 & 31 \\
Friends & 136 & 11 \\
Relatives & 49 & 3 \\
Newspaper & 13 & 16 \\
Self-research & 69 & 6 \\
Others & 28 & 4 \\
Average monthly expenditures & & 4 \\
Below 10,000 & & 46 \\
10,001 to 15,000 & 299 & 26 \\
15,001 to 20,000 & 165 & 46 \\
20,001 to 25,000 & 601 to 30,000 & 23 \\
Above 30,000 & 28 & 46 \\
\hline
\end{tabular}

The availability of host nation government scholarships is well established as a significant pull factor (Agarwal \& Winkler, 1985; Cummings, 1993). Given this, the popularity of Taiwan government scholarships could be viewed as a contributing factor for the expanding international student enrollments. That said participants' rationale for receiving Taiwan scholarships was not typically linked to financial hardship. Table 2 also summarizes the average monthly expenditures in Taiwan Dollars of the international student in Taiwan. Majority of the students mentioned that they spend below 10,000 NT a month with a value of 299 or $46 \%$. While 165 or $26 \%$ of the respondents claimed that they spent around 10,001 to 15,000 per month in Taiwan. In reality, scholarships in Taiwan provide financial support from one to four years of study and range from NT 25,000 monthly for undergraduate students to NT 30,000 monthly for graduate students. These findings suggest some discrepancy in living standards given that newly graduated college students in Taiwan earn from NT 26, 000 to 28, 000 monthly (CENS, 2008). 
In many nations incoming international students represent the premier source for university internationalization. As a newly emerging competitor host nation, Taiwan envisions its national system of higher education as an international center, where people from around the world come to learn from each other. As such the MOE government scholarships enhance the cultural composition of Taiwan universities' student bodies and contribute to institutional prestige (Lo \& Weng, 2005; Mok \& Tan, 2004). The immersion of international students among the local students represents, therefore, a pivotal objective of the university efforts for internationalization.

\subsection{Educational experiences in Taiwan}

With regards to the educational experiences in Taiwan, students are ask questions regarding the difficulties before coming to Taiwan, challenging aspects in Taiwan, difficulties with regards to educational aspects, and reasons in choosing a place of study in Taiwan. As a reminder, the items are analyzed initially by their weighted scores, items ranked number 1 is given a weight of 3 , ranked 2 is given a weight of 2 , while the ranked 3 is given a weight of 1 . Table 3 shows the result for the difficulties encountered before coming to Taiwan. The highest difficulty item is the application of the Taiwan Visa with 309 or $48 \%$, while the second difficulty item is the actual Scholarship applications with 190 or 29\%. The third most difficulty item is the Lack of sufficient information regarding course programs with 176 or $27 \%$. These results suggest that Taiwan should invest more efforts in enhancing its visa processing procedures for the international students coming to Taiwan. However, such enhancement might be limited to the political issues surrounding the country, which is beyond the discussion of the current study.

Table 3

Difficulties encountered before coming to Taiwan $(N=648)$

\begin{tabular}{lcc}
\hline \multicolumn{1}{c}{ Items } & $n$ & Weighted scores $^{\text {a }}$ \\
\hline Taiwan visa application & 309 & 708 \\
Scholarship applications & 190 & 389 \\
Lack of sufficient information regarding course programs & 176 & 324 \\
Selecting which school to apply & 150 & 301 \\
Emotional preparation & 137 & 237 \\
Communicating with Taiwan's university & 92 & 169 \\
\hline
\end{tabular}

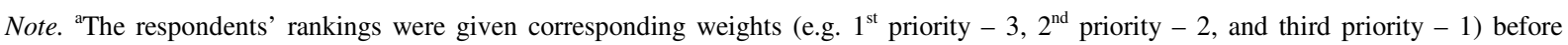
computing for the individual scores of each item.

With regards to the challenges encounter in Taiwan, international students mentioned that the most challenging aspect is the Memorizing Chinese character with 170 or $26 \%$. The second most challenging aspect is regarding the international students' social relationships in Taiwan with 172 or $27 \%$. The third most challenging aspect in Taiwan is the Adjusting to the weather with 166 or $26 \%$. Such results describe the difficulties of international student during their first few months in Taiwan, while some even suggest that they (international students) should be given enough orientation regarding the cultural and contextual issues regarding Taiwan, before even they travel to Taiwan.

With regards to the international students difficulties with regards to their study here in Taiwan, most students mentioned that there seem to exist a problem with the Understanding teachers' lessons/lectures with 216 or 33\%. Table 5 also shows that the item expressing or giving your opinion to your teacher with 190 or $29 \%$ and the item expressing or communicating in Chinese with 177 or $27 \%$. These results suggest that international students are not properly oriented in the educational system of Taiwan. Local faculty and staff should be brief with regards to the study habit of the international students as well. 


\section{Table 4}

Challenging aspects in Taiwan $(N=648)$

\begin{tabular}{|c|c|c|}
\hline Items & $n$ & Weighted scores ${ }^{a}$ \\
\hline Memorizing Chinese character & 170 & 402 \\
\hline Social relationship & 172 & 334 \\
\hline Adjusting to weather & 166 & 316 \\
\hline Cultural gap & 136 & 255 \\
\hline Adjusting to food & 124 & 252 \\
\hline Homesickness & 112 & 214 \\
\hline Transportation & 97 & 184 \\
\hline Being a non-English speaker & 70 & 155 \\
\hline
\end{tabular}

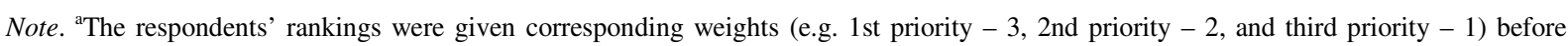
computing for the individual scores of each item.

\section{Table 5}

Difficulties with regards to educational aspects $(N=648)$

\begin{tabular}{lcc}
\hline \multicolumn{1}{c}{ Items } & $n$ & Weighted scores $^{\mathrm{a}^{2}}$ \\
\hline Understanding teachers' lessons/lectures & 216 & 451 \\
Expressing or giving your opinion to your teacher & 190 & 441 \\
Expressing or communicating in Chinese & 177 & 417 \\
Making oral presentation & 199 & 370 \\
Working on group project & 150 & 336 \\
Studying in a different educational system & 150 & 288 \\
Completing assignment on time & 63 & 131 \\
Managing your study load & 45 & 88 \\
\hline
\end{tabular}

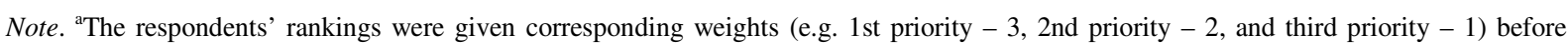
computing for the individual scores of each item.

Table 6 shows the reasons why the international students select their current school in Taiwan. The main reason is the item recommended by friends/classmates with 240 or $37 \%$. The second reason is the surrounding suitable for learning with 232 or $36 \%$. And lastly, the third reason is the direct contact form an institution in Taiwan with 127 or $20 \%$. Such results indicate that the power of the word of mouth exhibits the greatest influence in the international students' choice of schools. Hence, institutions should give outgoing international students a sort of orientation or a somewhat good impression, so as to aid in the recruitment of new international students.

\subsection{Social norms}

In recent years, the concept of social capital has captured the imagination and attention of an extensive range of scholars and professionals in various disciplines and practical arenas (Lin, 2008). Similarly, social capital has been used to shed light on the relationship between the micro-level of educational experience and the macro-level of social forces and structures (Burnheim, 2003). Scholars noted that the concept of social capital has expanded from an individual asset to a feature of communities and even nations (Portes, 1998). As such, multiple definitions, conceptualizations, and empirical measurements are generated (Dika \& Singh, 2002). However, the popularity of the concept of social capital has been accompanied by increasing controversy about 
its actual meaning and effects (Mouw, 2006; Portes, 2000).

Table 6

Reasons for choosing your current institution $(N=648)$

\begin{tabular}{lcc}
\hline \multicolumn{1}{c}{ Items } & $n$ & Weighted scores $^{\mathrm{a}}$ \\
\hline Recommended by friends/classmates & 240 & 568 \\
Surrounding suitable for learning & 232 & 485 \\
Direct contact form an institution in Taiwan & 127 & 266 \\
Degree program availability in English & 118 & 264 \\
Random chance & 110 & 223 \\
Informative website & 101 & 201 \\
Mandarin Chinese language program & 74 & 148 \\
Recommended by embassy & 59 & 125 \\
Existing student exchange program & 44 & 102 \\
\hline
\end{tabular}

Note. ${ }^{\text {a }}$ The respondents' rankings were given corresponding weights (e.g. $1^{\text {st }}$ priority $-3,2^{\text {nd }}$ priority -2 , and third priority -1 ) before computing for the individual scores of each item.

Simply, social capital can be defined as "the investment in social relations with expected returns in the marketplace" (Lin, 2002). This general definition is consistent with the works of noted scholars such as Bourdieu (1986), Burt (1992), Coleman (1988, 1990), Flap (1991, 1994), Lin (1982), Portes (1998), and Putnam (1993, 1995, 2000). During the late 1980s, education sociologists Bourdieu (1986) and Coleman (1988) both emphasized the functional value of social networks and group membership as resources which can be leveraged by individuals to obtain access to other resources. In addition, both authors placed much emphasis on the role of education and in particular the role of the social environment in determining educational outcomes.

In an educational setting social capital is defined "as the networks, together with norms, values, and understandings that facilitate cooperation with or among groups." (Healy, Cote, Helliwell, \& Field, 2001) In a study of Australian universities, Burnheim (2003) noted that it is important to understand: 1.) the particular role of social capital in the networks and networking within the universities, which themselves constitute capital; and 2.) the universities' roles in the creation of the norms, values, and understandings which enable networks to operate. Similarly, in a mixed method study regarding international students in Australia, Neri and Ville (2006) noted that poor social networks in unfamiliar cultural and educational institutions have an adverse impact on the wellbeing and academic performance of the students.

To further clarify the issues in the network and norms of international students in Taiwan, the following two sections shall focus on these parts, namely: the social norms and the cultural norms experienced in Taiwan. Table 7 shows the result when the international students were asked regarding their social interaction norms in Taiwan. Most students replied that they wanted to have more Taiwanese friends with total respondents of 259 or $40 \%$. This is followed by the item Taiwanese students have positive feelings towards me with total respondents of 205 or $32 \%$. The third item is I try my best to make friends with total respondents of 181 or $28 \%$. These three top results depict that international students are indeed accepting of Taiwanese students as not only their peers or classmates, but their friends as well.

Table 8 shows the international students aspects regarding their campus and classroom norms. The highest ranked is the item teachers encourage interaction with 144 or $22 \%$. While the second is the item teachers make special effort to help international student with 162 or $25 \%$. And the third is the item cultural differences are respected inside the school with 92 or $14 \%$. Note that although the percentage of the international students selecting the item is not high, however, by looking at their weighted scores, the international students selected these three items as the major norms in the campus and classroom category. 


\section{Table 7}

Social interaction norms $(N=648)$

\begin{tabular}{lcc}
\hline \multicolumn{1}{c}{ Items } & $n$ & Weighted scores $^{\mathrm{a}^{\mathrm{a}}}$ \\
\hline I want more Taiwanese friends & 259 & 623 \\
Taiwanese students have positive feelings towards me & 205 & 423 \\
I try my best to make friends & 181 & 358 \\
Taiwanese would like to know international students & 175 & 331 \\
Taiwanese students should take first step & 96 & 213 \\
It is difficult to make friends with Taiwanese students & 67 & 156 \\
My Chinese ability hinders me from making friends & 71 & 145 \\
I experience discrimination in Taiwan & 54 & 110 \\
Taiwanese students prefer fewer international students & 35 & 69 \\
\hline
\end{tabular}

Note. 'The respondents' rankings were given corresponding weights (e.g. $1^{\text {st }}$ priority $-3,2^{\text {nd }}$ priority -2 , and third priority -1 ) before computing for the individual scores of each item.

\section{Table 8}

Campus and classroom norms $(N=648)$

\begin{tabular}{lcc}
\hline \multicolumn{1}{c}{ Items } & $n$ & Weighted scores $^{\text {a }}$ \\
\hline Teachers encourage interaction & 144 & 568 \\
Teachers make special effort to help international student & 162 & 485 \\
Cultural difference is respected in school & 92 & 266 \\
Teachers understand problems of international student & 143 & 264 \\
Opportunity to learn from other culture & 110 & 223 \\
Feel included in class & 130 & 201 \\
Teachers understand cultural differences in learning & 81 & 158 \\
Classmates are accepting of cultural differences & 136 & 148 \\
Student of different groups work well & 136 & 125 \\
\hline
\end{tabular}

Note. ${ }^{\text {a }}$ The respondents' rankings were given corresponding weights (e.g. $1^{\text {st }}$ priority $-3,2^{\text {nd }}$ priority -2 , and third priority -1 ) before computing for the individual scores of each item.

Table 9 depicts the international students' circle of friends in different situations, such as: social and educational. Results indicate that the international students' educational and social time is mostly done with Taiwanese students, while their closest friends are still their friends from their own home country.

\subsection{Cultural norms}

The students are also asked regarding their perception of what is the accepted fact in the world today. Majority of the international students agrees that advancement in technology is the most prominent discovery of our generation, next to the learning of Mandarin Chinese language. Such results indicate that the changes in language needs are both ways, to the East the Mandarin Chinese and to the West the English language. Table 11 and table 12 shows the discouraging and distinct Taiwanese cultures which the international students felt unique and different, while some of items selected are considered norm to the Eastern or Asian culture. Much to the surprise of the selection of activities regarding night market as one of the major Taiwanese cultures the international students felt worth recalling. 


\section{Table 9}

International students' circle of friends $(N=648)$

\begin{tabular}{llc}
\hline \multicolumn{1}{c}{ Items } & $n$ & Weighted scores $^{\mathrm{a}}$ \\
\hline Studying and reviewing lessons & & $\mathbf{9 0 9}$ \\
$\quad$ Taiwanese students & 334 & 592 \\
Students from other countries & 236 & 411 \\
Students from their own country & 211 & $\mathbf{9 0 3}$ \\
During social activities & 345 & 745 \\
Taiwanese students & 303 & 458 \\
Students from other countries & 244 & 716 \\
Students from their own country & & $\mathbf{7 9 1}$ \\
Closest friends & 289 & 391 \\
Taiwanese students & 293 & 197 \\
Students from other countries & & \\
Students from their own country & & \\
\hline
\end{tabular}

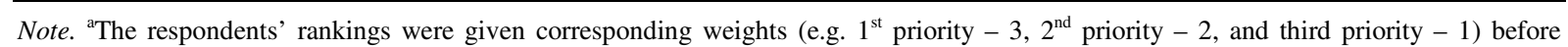
computing for the individual scores of each item.

\section{Table 10}

Accepted fact in today's society $(N=648)$

\begin{tabular}{lcc}
\hline \multicolumn{1}{c}{ Items } & $n$ & Weighted scores $^{\text {a }}$ \\
\hline Technology connects people & 180 & 393 \\
Technology makes the world smaller & 175 & 384 \\
Learning Mandarin Chinese is the current trend & 184 & 364 \\
Local traditional customs should be maintain & 166 & 347 \\
People should leave together in harmony & 124 & 275 \\
English is most widely spoken language & 86 & 196 \\
\hline
\end{tabular}

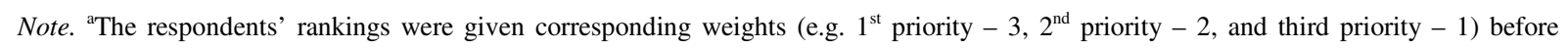
computing for the individual scores of each item.

\section{Table 11}

Discouraging Taiwanese cultural norms $(N=648)$

\begin{tabular}{|c|c|c|}
\hline Items & $n$ & Weighted scores $^{\mathrm{a}}$ \\
\hline Chopsticks & 139 & 366 \\
\hline Fortune telling & 127 & 260 \\
\hline Poultry slaughtering in market & 83 & 181 \\
\hline Eating hotpot & 60 & 111 \\
\hline Eating bethel nut & 55 & 102 \\
\hline Incense burning & 53 & 95 \\
\hline Going KTV & 47 & 93 \\
\hline Shopping at night market & 23 & 36 \\
\hline
\end{tabular}

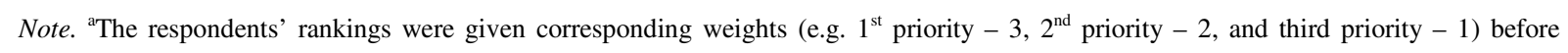
computing for the individual scores of each item. 


\section{Table 12}

Distinct Taiwanese cultures $(N=648)$

\begin{tabular}{|c|c|c|}
\hline Items & $n$ & Weighted scores $^{\mathrm{a}}$ \\
\hline Shopping at night market & 289 & 662 \\
\hline Eating at night market & 220 & 493 \\
\hline Garbage segregation (sorting of garbage) & 269 & 484 \\
\hline Poultry slaughtering in market & 134 & 299 \\
\hline Eating hotpot & 148 & 279 \\
\hline Going KTV & 82 & 172 \\
\hline Eating bethel nut & 71 & 157 \\
\hline Environmentally conscious & 66 & 134 \\
\hline Chopsticks & 12 & 32 \\
\hline Incense burning & 12 & 26 \\
\hline Fortune telling & 15 & 25 \\
\hline
\end{tabular}

Note. ${ }^{\text {a }}$ The respondents' rankings were given corresponding weights (e.g. $1^{\text {st }}$ priority $-3,2^{\text {nd }}$ priority -2 , and third priority -1 ) before computing for the individual scores of each item.

\section{Implications and Conclusion}

This article contributes to discourse examining the opportunities and challenges of international student enrollments in institutions of higher learning around the globe. In scope it details an empirical study exploring the dispositions of international students in terms of their academic and social spheres. The use of quantitative methods provided clarity and extended critical interpretations of the issues and dilemmas surrounding the international student experience. The Taiwan government efforts to develop national policies and set targets to attract substantial numbers of international students are impressive. Yet ingoing international students to Taiwan universities experience unhappiness and disorientation on arrival from their home nations. Most are successful in terms of building a circle of friends and booming happier over time. However, the friendships are typically with international student peers from the same nation, which provides fellowship and empathy but limited opportunities for connections with Taiwan students and to learn about local culture and institutions.

With regards to the benefits and dilemmas associated with the international student population in terms of institutional commitments for the expansion of internationalization for Taiwan's higher education institutions. Taiwan's higher education institutions are heavily committed to increase the numbers of international students. However, some issues are needed to be taken into account such as the proper orientation of incoming and outgoing international students. In addition, faculty and staff should also undergone proper training or orientation regarding on how to handle issues with the international students. The majority of international students make little or no use of formal university sanctioned organizations widely associated with the benefits of social capital as noted in the literature. Many international students accept paid employment, often for long hours and with limited social capital benefits besides language improvements. These international students could derive the benefits of social capital by committing a greater amount of time to university organizations and fewer hours to paid employment. As well many international students report a high degree of residential instability, which disrupts both their social connections and academic study.

\section{References:}

Agarwal, V. B., \& Winkler, D. R. (1985). Foreign demand for United States higher education: a study of developing countries in the eastern hemisphere. Economic Development and Cultural Change, 33(3), 623-644. <http://dx.doi.org/10.1086/451482> 
Altbach, P. G. (1997). Comparative higher education: Knowledge, the university and development. Chestnut Hill: Center for International Higher Education, Boston College and Ablex Publishing Corporation.

Altbach, P. G. (2003). Why the United States will not be a market for foreign higher education products: A case against GATS. Retrieved September 26, 2008, from http://www.bc.edu/bc_org/avp/soe/cihe/newsletter/News31/text003.htm

Bohm, A., Meares, D., \& Pearce, D. (2002). Global student mobility 2025: Forecast of the global demand for international higher education. Sydney: IDP Education.

Bourdieu, P. (1986). The forms of capital. In J. G. Richardson (Ed.), Handbook of theory and research for the sociology of education (pp. 241-258). Westport, CT: Greenwood Press.

Burnheim, C. (2003, July 3). Networks and social capital in Australian Universities. Paper presented at the Trading public good in the higher education market, University of Twente, Netherlands.

Burt, R. S. (1992). Structural holes: The social structure of competition. Cambridge, MA: Harvard University Press.

CENS. (2008). Easy, low-paying jobs gain popularity in Taiwan. Retrieved August 15, 2008, from http://www.cens.com/cens/html/en/news/news_inner_23920.html

Chan, D., \& Ng, P. T. (2008). Similar agendas, diverse strategies: The quest for a regional hub of higher education in Hong Kong and Singapore. Paper presented at the 2008 CESHK Annual Conference.

Chin, M. C., \& Ching, G. S. (2009). Trends and indicators of Taiwan's higher education internationalization. The Asia-Pacific Education Researcher, 18(2), 185-203. <http://dx.doi.org/10.3860/taper.v18i2.1322>

Cohen, L., Manion, L., \& Morrison, K. (2007). Research methods in education. New York: Routledge.

Coleman, J. S. (1988). Social capital in the creation of human capital. The American Journal of Sociology, 94 , 95-120. <http://dx.doi.org/10.1086/228943>

Coleman, J. S. (1990). Equality and achievement in education. Boulder, CO: Westview Press.

Cronbach, L. J. (1951). Coefficient alpha and the internal structure of tests. Psychometrika, 16, 197-334. $<$ http://dx.doi.org/10.1007/BF02310555>

Cubillo, J., Sanchez, J., \& Cervino, J. (2006). International students' decision-making process. International Journal of Educational Management, 20, 101-115. <http://dx.doi.org/10.1108/09513540610646091>

Cummings, W. K. (1993). Global trends in international study. In G. Craufurd (Ed.), International investment in human capital. New York: Institute of International Education.

Dika, S. L., \& Singh, K. (2002). Applications of social capital in educational literature: A critical synthesis. Review of Educational Research, 72(1), 31-60. <http://dx.doi.org/10.3102/00346543072001031>

Dillman, D. A. (1999). Mail and internet surveys: The tailored design method (2nd ed.). New York, NY: John Wiley \& Sons.

Dillman, D. A., Tortora, R. D., \& Bowker, D. (1998). Principles for constructing web surveys. Retrieved November 29, 2008, from http://survey.sesrc.wsu.edu/dillman/papers/websurveyppr.pdf

Dillman, D. A., Tortora, R. D., Conradt, J., \& Bowker, D. (1998). Influence of plan versus fancy design on response rates of web surveys. Retrieved November 29, 2008, from http://survey.sesrc.wsu.edu/dillman/papers/asa98ppr.pdf

Flap, H. D. (1991). Social capital in the reproduction of inequality. Comparative Sociology of Family, Health and Education, 20, 6179-6202.

Flap, H. D. (1994). No man is an island: The research program of a social capital theory. Paper presented at the World Congress of Sociology, Bielefeld, Germany.

Fry, G. (1984). The economic and political impact of study abroad. Comparative Education Review, 28(2), 203-220. <http://dx.doi.org/10.1086/446431>

Healy, T., Cote, S., Helliwell, J. F., \& Field, S. (2001). The well-being of nations: The role of human and social capital. Paris, France: Organisation for Economic Co-operation and Development.

JWT Education. (2008). International student mobility in East Asia: Executive summary: British Council. Retrieved from

http://www.eahep.org/web/images/Malaysia/bc\%20-\%20asia\%20student\%20mobility\%20-\%20summar y.pdf

Kemp, S. (1995). The global market for foreign students. Adelaide: University of Adelaide.

Kirp, D. L. (2003). Shakespeare, Einstein, and the bottom line: The marketing of higher education. Cambridge, MA: Harvard University Press.

Kishun, R. (2007). The internationalisation of higher education in South Africa: Progress and challenges. Journal of Studies in International Education, 11(3/4), 455-469. $<$ http://dx.doi.org/10.1177/1028315307304184>

Ko, S. L. (2008). International students in Taiwan at an all-time high. Retrieved June 11, 2008, from http://www.taipeitimes.com/News/taiwan/archives/2008/02/12/2003400913 
Chou, C. P., Roberts, A., \& Ching, G. S.

Kwiek, M. (2005). The university and the state in a global age: Renegotiating the traditional social contract? European Educational Research Journal, 4(4), 324-342. <http://dx.doi.org/10.2304/eerj.2005.4.4.1>

Lin, N. (1982). Social resources and instrumental action. In P. V. Marsden \& N. Lin (Eds.), Social structure and network analysis (pp. 131-145). Beverly Hills, CA: Sage.

Lin, N. (2002). Social capital: A theory of social structure and action. London, UK: Cambridge University Press.

Lin, N. (2008). A network theory of social capital. In D. Castiglione, J. W. van Deth \& G. Wolleb (Eds.), The handbook of social capital (pp. 50-69). New York, NY: Oxford University Press.

Lo, Y. W., \& Weng, F. Y. (2005). Taiwan's responses to globalization: Internationalization of higher education. In K. H. Mok \& R. James (Eds.), Globalization and higher education in East Asia. Singapore: Marshall Cavendish Academic.

Mazzarol, T. (1998). Critical success factors for international education marketing. International Journal of Educational Management, 12(4), 163-175. <http://dx.doi.org/10.1108/09513549810220623>

McMahon, M. E. (1992). Higher education in a world market: an historical look at the global context of international study. Higher Education Policy, 24(4), 465-482.

Mok, K. H., \& Tan, J. (2004). Globalization and marketization in education: A comparative analysis of Hong Kong and Singapore. UK: Edward Elgar Publishers.

Mouw, T. (2006). Estimating the causal effect of social capital: A review of recent research. Annual Review of Sociology, 32, 79-102. <http://dx.doi.org/10.1146/annurev.soc.32.061604.123150>

Neri, F., \& Ville, S. (2006). The social capital experience of international students in Australia: The Wollongong experience [Electronic Version]. Economics Working Papers, from http://ideas.repec.org/p/uow/depec1/wp06-19.html

Nunnally, J. C., \& Bemstein, L. H. (1994). Psychometric theory. New York: McGraw-Hill.

OECD. (2006). Education at a glance: OECD indicators 2006. Paris: Organisation for Economic Co-operation and Development.

Olsen, A. (2003). E-Learning in Asia: Supply and demand. Retrieved September 25, 2008, from http://www.bc.edu/bc_org/avp/soe/cihe/newsletter/News30/text004.htm

Pinar, W. F., Reynolds, W. M., Slattery, P., \& Taubman, P. M. (1996). Understanding curriculum: An introduction to the study of historical and contemporary curriculum discourses. New York: Peter Lang.

Portes, A. (1998). Social capital: Its origins and applications in modern sociology. Annual Review of Sociology, 24, 1-24. <http://dx.doi.org/10.1146/annurev.soc.24.1.1>

Portes, A. (2000). The two meanings of social capital. Sociological Forum, 15(1), 1-12. $<$ http://dx.doi.org/10.1023/A:1007537902813>

Project Atlas. (2004). Atlas of student mobility. Retrieved September 20, 2008, from http://www.atlas.iienetwork.org/

Putnam, R. D. (1993). The prosperous community: Social capital and public life. The American Prospect, 13, $35-42$.

Putnam, R. D. (1995). Bowling alone: America's declining social capital. Journal of Democracy, 6(1), 65-78. $<$ http://dx.doi.org/10.1353/jod.1995.0002>

Putnam, R. D. (2000). Bowling alone: The collapse and revival of American community. New York, NY: Simon and Schuster.

Roberts, A., \& Ching, G. S. (2010). Social capital and contemporary trends: A mixed methods study of international students in a Taiwan university. Paper presented at the Asia Pacific Professional Leaders in Education Conference.

Roberts, A., Chou, P., \& Ching, G. (2010). Contemporary trends in East Asian higher education: Dispositions of international students in a Taiwan university. Higher Education, 59(2), 149-166. $<$ http://dx.doi.org/10.1007/s10734-009-9239-4>

Sirowy, L., \& Inkeles, A. (1985). University-level student exchanges: The U.S. role in global perspective. In E. G. Barber (Ed.), Foreign student flows: Their significance for American higher education. New York: Institute of International Education.

Smart, D., \& Ang, G. (1993). The origins and evolution of the commonwealth full-fee paying overseas student policy 1975-1992. In W. J. Peachment \& J. Williamson (Eds.), Case studies in public policy (pp. 111-128). Perth: Public Sector Research Unit.

Smith, M. P., \& Guarnizo, L. E. (Eds.). (1998). Transnationalism from below (Vol. 6). New Brunswick: Transaction Publishers. 